\title{
CONF-950509-1
}

DOE/NASA/50306-6

NASA TM-106753

\section{A New Tribological Test for Candidate Brush Seal Materials Evaluation}

James A. Fellenstein

Ohio Aerospace Institute Cleveland, Ohio

and

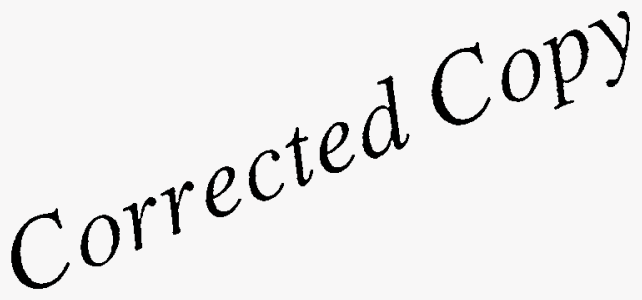

Christopher DellaCorte

National Aeronautics and Space Administration

Lewis Research Center

Work performed for

U.S. DEPARTMENT OF ENERGY

Conservation and Renewable Energy

Office of Vehicle and Engine R\&D

Prepared for the

Annual Meeting

sponsored by the Society of Tribologists and Lubrication Engineers

Chicago, Illinois, May 15-20, 1995

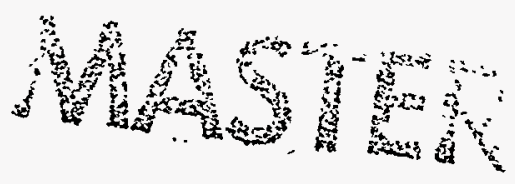




\section{DISCLAIMER}

This report was prepared as an account of work sponsored by an agency of the United States Government. Neither the United States Government nor any agency thereof, nor any of their employees, makes any warranty, express or implied, or assumes any legal liability or responsibility for the accuracy, completeness, or usefulness of any information, apparatus, product, or process disclosed, or represents that its use would not infringe privately owned rights. Reference herein to any specific commercial product, process, or service by trade name, trademark, manufacturer, or otherwise does not necessarily constitute or imply its endorsement, recommendation, or favoring by the United States Government or any agency thereof. The views and opinions of authors expressed herein do not necessarily state or reflect those of the United States Government or any agency thereof. 


\section{DISCLAIMER}

Portions of this document may be illegible in electronic image products. Images are produced from the best available original document. 


\title{
A New Tribological Test for Candidate Brush Seal Materials Evaluation
}

\author{
James A. Fellenstein \\ Ohio Aerospace Institute \\ 22800 Cedar Point Road \\ Cleveland, Ohio 44142 \\ and \\ Christopher DellaCorte \\ National Aeronautics and Space Administration \\ Lewis Research Center \\ Cleveland, Ohio 44135
}

\begin{abstract}
A new tribological test for candidate brush seal materials evaluation has been developed. The sliding contact between the brush seal wires and their mating counterface joumal is simulated by testing a small tuft of wire against the outside diameter of a high speed rotating shaft. The test configuration is similar to a standard block on ring geometry.

The new tester provides the capability to measure both the friction and wear of candidate wire and counterface materials under controlled loading conditions in the gram to kilogram range. A wide range of test condition speeds $(1$ to $27 \mathrm{~m} / \mathrm{s})$, temperatures $\left(25\right.$ to $\left.700^{\circ} \mathrm{C}\right)$, and loads $(0.5$ to $10 \mathrm{~N}$ ) enables the simulation of many of the important tribological parameters encountered by turbine engine brush seals.

This paper describes the new test rig and specimen configuration and presents initial data for candidate seal materials comparing tuft test results and wear surface morphology to field tested seal components.
\end{abstract}

\section{Introduction}

Gas turbine engines are the preferred power source for modern aircraft because of their high thrust to weight ratios. The thrust of a turbine engine results from the momentum imbalance between the low velocity intake air and the high velocity exhaust air. The intake air has two possible paths through the turbine engine: Air that passes through the combuster along the gas path is the primary airflow; air which does not travel through the combuster is the secondary airflow. This secondary flow includes bypass air for high bypass ratio turbofans, internal engine cooling air, external bleed air for cabin air conditioning and accessory devices, and air leakage past seals. An engine with reduced secondary flow leakage past seals produces approximately 4 to 6 percent more power while reducing the specific fuel consumption by 3 to 5 percent. 1,2

Brush seals have been generating a great deal of interest as replacements for labyrinth seals in secondary air flow systems due to their potential for improved air-to-air sealing and their tolerance of shaft excursions. Current research has demonstrated that a reduction of 90 percent in internal leakage can be obtained by replacing the best knife edged labyrinth seal with a brush seal. 1,3

A brush seal is made up of a stationary brush ring and a rotating land. Each brush ring consists of densely packed bristles bound by front and back plates (Figure 1). These bristles are made from short lengths (about $1.5 \mathrm{~cm}$ ) of fine metallic wire typically $0.71 \mathrm{~mm}(0.0028 \mathrm{in}$.) in diameter. The bristles are angled from the radial position in the direction of the shaft rotation.

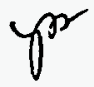


This permits the bristles to deflect rather then buckle during shaft excursion. The compliance of the brush seal accounts for its long term effectiveness.

Brush seals, however, also have drawbacks. Brush seals are designed with approximately $0.127 \mathrm{~mm}(0.005 \mathrm{in}$.) interference between the brush and land. The lowest leakage rates of a brush seal occur before the interference is lost due to wear. Also, since the brush is in contact with the shaft, an additional frictional drag or energy loss will be incurred. This frictional loss must be compensated for by the thrust savings due to the reduction of the internal flow leakage to make brush seals favorable. To reduce the energy loss, the frictional force between the brush and the land must be minimized. In addition, any improvement in the wear properties of the brush and land tribopair will improve the long term effectiveness of the seal. Current state of the art brush seals under flight testing last approximately 2,000 hours. This is sufficient for military applications but far from acceptable for commercial airlines which have a goal of 10,000 hours. ${ }^{4}$

The current state-of-the-art brush seal materials are chosen for their high temperature capabilities and proven performance characteristics in turbine engine environments. Metal brush wire materials are either cobalt or nickel-based superalloys. Examples include: H25, a chromium-cobalt-nickel superalloy, and I718, a nickel-chromium-iron superalloy. Experimental ceramic brush wires include silicon carbide ( $\mathrm{SiC}$ ) and aluminum oxide ( $\left.\mathrm{Al}_{2} \mathrm{O}_{3}\right)$. Depending on the expected engine life, the mating journal is either a bare superalloy or a superalloy coated with various hard coatings such as aluminum oxide $\left(\mathrm{Al}_{2} \mathrm{O}_{3}\right)$ or chromium carbide $\left(\mathrm{Cr}_{3} \mathrm{C}_{2}\right)$. Compared with replacing a brush ring, the cost of refinishing a shaft is high. Therefore, to prevent excessive damage to the joumal, the coatings applied are somewhat abrasive resulting in the preferential wear of the brush seal.

To date, the primary emphasis of the research conducted on brush seals has been to describe their flow leakage based on pressure differentials and known seal geometries. ${ }^{1-4}$ Materials characterization has only been a secondary concern despite the fact that the wear prevents these seals from achieving life expectancy goals in commercial systems.

In full seal testing or testing with a fixed seal to shaft spacing, the contact force between the brush and shaft changes as the brush and/or rotor wears. This wearing of either component confounds the "true" measure of the tribological characteristics of the material pair tested. The research described in this paper was conducted with two objectives: to develop a test technique for examining the tribological characteristics of brush seals, and to begin the screening of candidate materials for brush seal applications.

The two primary characteristics studied are the friction coefficient for each brush/journal tribopair and their corresponding wear factors. To accurately determine these characteristics, small portions of a brush seal (a tuft) are tested with a known constant normal load. Unlike previous friction and wear data based on full seal or fixed seal to rotor spacing, the test configuration used in this work provides a fixed contact force between the brush seal tuft and journal. A foil bearing test rig was modified for testing the brush seal tufts at the NASA Lewis Research Center. Modifications include the development of tuft specimens, a two-degree-offreedom gimbal for specimen mounting and a data acquisition system for real-time monitoring of the test variables.

\section{Specimen - Materials and Preparation}

Journal Specimens. The joumals evaluated during this initial study were a nickel-based superalloy designated 1718. Its composition is provided in Table 1 and is considered a reference material because of its high temperature capabilities along with its proven reliability in turbine engines.

The test journals are $38.1 \mathrm{~mm}$ (1.5 in.) in diameter and $53.3 \mathrm{~mm}$ (2.1 in.) long. The journals can accommodate six wear tracks each approximately $3 \mathrm{~mm}$ wide. Before the initial run of each test, the journals are cleaned to remove any residual contaminants by rinsing in ethyl alcohol followed by a scrubbing with levigated alumina and water. Finally, the journal is rinsed with distilled water and dried. 
Brush Specimens. Figure 2 shows a typical brush seal tuft. H25, a nickel-cobalt based superalloy was used for this initial testing and its composition is given in Table 1 . The brush seal samples are made by first winding fully annealed wire (typically $0.71 \mathrm{~mm}$ diameter) into a $25 \mathrm{~cm}$ long bundle with 920 wires. The bundle is then slipped into a plastic shrink tubing and heated with a hot air gun which forces the bristles together into a tight bundle. After the tube is shrunk, the bundle is cut into six pieces approximately $4 \mathrm{~cm}$ long. Each piece is then partially stripped and slipped into a $1.6 \mathrm{~cm}$ long 1718 tube or collar. After the bristles are aligned and set with an approximate $0.25 \mathrm{~mm}(0.010 \mathrm{in}$.) overhang for welding, the bristles and collar are shrink wrapped again. Next, the bristles are TIG welded into the collar. Finally, the second shrink wrap is removed and the tuft is diamond ground (150 grit) with water as the lubricant to a $45^{\circ}$ angle and a fence height of $1.27 \mathrm{~mm}(0.050 \mathrm{in}$.). After the brush seal samples are manufactured, the samples are ultrasonically cleaned for five minutes in acetone and then in methyl alcohol. Table 2 lists some of the physical characteristics of the brush specimens and current brush seal designs.

\section{Test Apparatus and Procedures}

Modified Foil Bearing Test Rig. Figure 3a shows the cross section of the modified foil bearing test rig. The test rig consists of a test spindle which is supported by two preloaded angular contact ball bearings. The test journals are mounted on the test spindle. An insulated housing with oil and water access for bearing cooling and lubrication protects the bearings. A $3 / 4$ hp variable speed DC motor with a pulley ratio of $6: 1$ is used to drive the test spindle at speeds from 1,000 to 17,000 RPM. A removable furnace with eight 500 Watt quartz lamps is used to maintain the test section at temperatures to $700^{\circ} \mathrm{C}\left(1292^{\circ} \mathrm{F}\right)$.

Gimbal design. Because brush seals operate at low contact pressures, typically less than $69 \mathrm{kPa}(10 \mathrm{psi})$, the sample mounting device had to be stable with the light test loads, $0.98 \mathrm{~N}$ $(100 \mathrm{~g})$ or less, and high rotational test speeds, $24 \mathrm{~m} / \mathrm{s}$ (79 ft/s). A gimbal with two degrees of freedom was chosen because it could be balanced for accurate loading, maintain a constant contact force between the seal and land, and designed to avoid any resonance at anticipated testing speeds. A counter weight with a fine adjustment is used for balancing the system. The system is sensitive enough that a two gram weight can topple the gimbal. A low stiffness paddle damper is used to reduce high frequency noise.

Instrumentation and Data Acquisition System. A computer data acquisition system is used for continuous monitoring of the test conditions. During each test run the friction force is measured by a \pm 250 gram linear voltage displacement transformer (LVDT) Load Cell. Every three minutes, the data acquisition system samples the friction force 100 times over a $5 \mathrm{~s}$ period. The computer then averages the 100 friction force values and calculates a coefficient of friction using the known test load. As a backup system, a strip chart recorder is used to measure the friction and to verify the zero point of the load cell. In addition to monitoring the friction, the journal temperature and speed are recorded every three minutes using a thermocouple and an optical probe tachometer respectively. An oscilloscope chart recorder was also available for real time viewing of the friction and speed traces. Additional instrumentation is used to monitor the other safety devices of the rig. For a complete description of the additional test rig capabilities see Bhushan .5

Test Procedure. Each test consists of nine, two-hour test runs for a total of eighteen hours of testing per $\mathrm{H} 25$ brush specimen. The test results for the nine runs were averaged to determine an overall average friction coefficient. Table 3 lists the test conditions during these studies. These conditions were selected to simulate start-up and full-speed running conditions which may be encountered in a engine brush seal.

To begin the test setup, the journal specimens are mounted on the test spindle with a Total Indicated Runout (T.I.R.) of less than $0.013 \mathrm{~mm}(0.0005 \mathrm{in}$.). Next, the brush specimens are secured in the vertical arm of the gimbal and the gimbal is leveled with a bull's-eye level. For high temperature tests the gimbal arm is leveled with approximately $2 \mathrm{~mm}$ between the brush and journal to accommodate thermal growth. Figure $3 b$ shows the test position for the brush seal samples. The furnace is then closed and the motor is started. For high temperature tests, the 
furnace is allowed to heat up to $650^{\circ} \mathrm{C}$ then an additional fifteen minutes is allotted for the test system to reach thermal equilibrium. After thermal equilibrium is established, the gimbal is balanced so a $2 \mathrm{~g}$ load will force the tuft specimen onto the journal surface. The $2 \mathrm{~g}$ load is then removed and the LVDT load cell is zeroed.

Test Analysis. The cross sectional area of the wear track is measured after the final test run at four locations at $90^{\circ}$ intervals around the journal with a stylus type profilometer. Starting and ending points for each trace are noted by either well defined shoulders in the profilometer trace or by visual inspection during the trace with a video camera. After completing the four traces, the average wear area is calculated and multiplied by the joumal circumference to determine the wear volume. Finally, the wear factor is calculated based on the wear volume divided by the test load and sliding distance.

To determine the wear of the brush samples, photomacrographs (magnification of 40X) are taken before the initial test run and after every third run. To ensure accurate measurement of the samples, a few bristles on the outside surface of the sample are either scarred with a scalpel or cut short to act as reference points. Eight reference locations are recorded and averaged to find the mean brush wear per test interval. This value is multiplied by the cross sectional area of the sample to determine the mean wear volume and the wear factor is calculated. Weight loss measurements are not used to estimate wear due to the confounding effects of oxidation.

After testing, selected brush specimens were subjected to energy dispersive spectroscopy (EDS) to qualitatively determine if any material transferred between the brush and journal. The journal specimens are too large to fit into the SEM chamber for accurate measurement.

\section{Results and Discussion}

The two tribological characteristics studied in this initial materials evaluation are the friction coefficient $(\mathrm{m})$ and the wear factor $(\mathrm{K})$, defined as:

$$
\begin{aligned}
& \mu=\frac{F}{N} \\
& K=\frac{V_{W}}{N * D}
\end{aligned}
$$

The coefficient of friction is the ratio of the measured frictional force $(F)$ to the normal load $(N)$. The wear factor is the ratio of the material volume worn $\left(\mathrm{V}_{\mathrm{W}}\right)$ to the normal load $(\mathrm{N})$ and the sliding distance (D). A physical interpretation of the wear factor is presented in Table 4 and is elaborated in reference 6 . To achieve the goal of 10,000 hours with only $0.127 \mathrm{~mm}$ of bristle wear, the brush wear factor for the high speed and low load tests would have to be approximately $1.36 \times 10^{-9} \mathrm{~mm}^{3} \mathbb{N} \cdot \mathrm{m}$.

Journal Wear. The journal wear tracks, after eighteen hours of testing with a H25 tuft, showed either mild polishing or more severe, abrasive type wear. Table 5 shows the 1718 journal wear factors for each test configuration. The journal wear factors ranged from $7.3 \times 10^{-8}$ to $2.6 \times 10^{-5} \mathrm{~mm}^{3} \mathbb{N} \cdot \mathrm{m}$. A photomicrograph of a typical wear track is shown in Figure 4. Based on the interpretive wear factor scale presented in Table 4 , the journal wear for each test configuration would be classified as moderate or low. The effect of increasing the test temperature from $20^{\circ} \mathrm{C}$ to $650^{\circ} \mathrm{C}$ was to reduce the overall journal wear. This may be caused by the formation of a lubricious oxide layer on the journal surface.

In full scale brush seal testing the contact force at the seal interface continually changes, therefore, the wear factor for such tests cannot be determined. Consequently, the wear scar depths must be used to compare the results of the tuft and the full scale brush seal tests.

The normalized wear scar depths per million revolutions (mm/Mrev) for the tuft tests which lasted 18 hours ranged from 0.43 to $179 \mathrm{~mm} / \mathrm{Mrev}$ (Table 5). Tests completed by other researchers on full scale brush seals showed rotor wear tracks ranging from 0.025 to $0.193 \mathrm{~mm} / \mathrm{Mrev}$ with $\mathrm{H} 25$ seal tested against R80 (a nickel chromium superalloy) for 46 hours 
at $377^{\circ} \mathrm{C}\left(765^{\circ} \mathrm{F}\right) 2$. In comparison with these tests, the wear for the journals tested are similar or higher when projected over time as expected with the constant contact force.

It is unclear why tests at low speed and lighter loads resulted in higher journal wear depths at both 20 and $650^{\circ} \mathrm{C}$. This may be due to rig effects such as the dynamics of the loading mechanism and continues to be investigated. Notwithstanding, at high speeds, where brush seals operate for the vast majority of their lives, the data obtained from the tests compares favorably with field and full scale bench tests.

Brush Wear. The H25 brush specimens tested showed abrasive wear on the brush interface surface. Bristle ends were worn and appeared polished with wear debris between the bristles and on the collar. In one case the wear rate was so high that a second tuft was required to complete the last three test runs.

The brush wear factors for the tests completed were moderate to low and ranged from $6.0 \times 10^{-7}$ to $8.1 \times 10^{-5} \mathrm{~mm}^{3} \mathrm{~N} \cdot \mathrm{m}$ (Figure 5). Increases in either the temperature or surface speed resulted in lower brush wear factors. To compare the bristle wear results of the tuft tests and the full scale brush seal tests, the change in bristle length due to wear must be used like the comparisons made for joumal wear.

Hendricks et. al. ${ }^{2}$ reported the wear of a $\mathrm{H} 25$ brush seal tested against a superalloy rotor was $0.001 \mathrm{~mm} / \mathrm{Mm}$ (tuft wear per million meters of sliding) after 46 hours testing. For the tuft tests, the bristle wear ranged from 0.039 to $6.150 \mathrm{~mm} / \mathrm{Mm}$ (Table 6). These values are higher than reported for full scale brush seals. This difference may be due to load reduction experienced in full scale brush seals due to interference wear and pressure induced hydrodynamic lift. Even though the wear is higher for the tuft testing, as expected, the wear mechanisms are the same as experienced in the full scale brush seal testing. As demonstrated by Derby and England 7 and Hendricks et al., 2 in full scale brush seal testing, the bristles exhibited abrasive wear at the interface and a typical build up of material at the trailing edge of the bristles. Both phenomena were observed within the brush tuft testing. Photographs of typical bristle ends for full scale brush testing and tuft testing are included in Figures 6 and 7.

Coefficient of Friction. An example of a typical average coefficient of friction versus time plot is included in Figure 8. The error bars represent the standard deviation of the nine test runs. The average friction coefficient for each of the test configurations is presented in Figure 9. The friction coefficients ranged from 0.25 to 0.47 (Table 7). In general, coefficient of friction was constant during each test. In full scale tests, the friction force is time dependent because of the changing contact force at the seal interface. Again the effect of temperature was to reduce the friction coefficient. As suggested previously, this reduction may be caused by the lubricious oxide layer formation on the journal surface. 8

Surface Analysis. Energy dispersive spectroscopy (EDS) was employed on selected journal wear tracks and brush specimens to determine if any material transfer occurred between the brush and journal at the tuft-journal interface.

Three H25 brush specimens were selected for EDS analysis. The composition of 1718 and $\mathrm{H} 25$ are shown in Table 1 . The key elements to determine if any material transferred from the $I 718$ joumals to the brush specimens are $\mathrm{Mo}, \mathrm{Nb}, \mathrm{Ti}$, and Al. Each of the three brush samples tested against an 1718 joumal showed $\mathrm{Mo}, \mathrm{Nb}$, and $\mathrm{Al}$ confirming qualitatively that there is material transfer. An example of the brush specimen EDS analysis is presented in Figure 10. Journals were not examined because they could not be positioned in the SEM-EDS analytical chamber to allow analysis.

\section{Concluding Remarks}

The test apparatus and procedure developed for this research successfully duplicates the wear and friction characteristics encountered in full-scale brush seal testing. The wear of both the journal and brush specimens studied in this research appear to experience the same abrasive wear mechanism seen in full scale testing and yield similar morphological results. 
The journal wear factors measured were similar or slightly higher than those for full-scale brush seal testing. The same was true for the brush wear factors. This was probably caused by the constant loading conditions experienced in the tuft test. The coefficient of friction values of the tuft specimens are approximately equal to the full-scale tests before the interference is excessively worn.

The tuft tester successfully provided direct friction and wear data on candidate seal materials under controlled load, speed and temperature conditions. To the authors' knowledge, this paper represents the first reporting of this type of brush seal simulation. This data directly showed the general effects of the tribological conditions on wear and friction that can only be inferred from full seal or engine tests. The tuft tester developed also represents a significant achievement in tribotesting in that friction and wear data can be accurately and conveniently measured under controlled conditions. It is recommended that further work be completed with journal coatings and wire materials to reduce wear. Furthermore, this data needs to be incorporated into full scale seal testing for corroboration and continued materials development.

\section{References}

1. Holle, G.F. and Krishan, M.R., "Gas Turbine Engine Brush Seal Applications," AIAA Paper No. 90-2142, 1990.

2. Hendricks, R.C., et al., "Relative Performance Comparison Between Baseline Labyrinth and Duel Brush Compressor Discharge Seals in A T-700 Engine Test." ASME Paper 94 GT-266.

3. Ferguson, J.G., "Brushes as High Performance Gas Turbine Seals," ASME Paper No. 88GT-182, 1988.

4. Flower, R., "Brush Seal Development System," AIAA Paper No. 90-2143, 1990.

5. Bhushan, B., "Development of r.f.-sputtered chromium oxide coating for wear applications," Thin Solid Films, Vol. 64, 1979 pp. 231-241.

6. DellaCorte, C., "Tribological Composition Optimization of Chromium-Carbide-Based Solid Lubricant Coatings For Foil Gas Bearings At Temperatures to $650^{\circ} \mathrm{C}$," Surface and Coating Technology, Vol. 36, 1988 pp. 87-97.

7. Derby, J., and England, R., "Tribopair Evaluation of Brush Seal Applications," AIAA Paper 92-3715.

8. Sliney, H.E., and DellaCorte, C., "The Friction and Wear of Ceramic/Ceramic and Ceramic/Metal Combinations in Sliding Contact," Lubrication Engineering, Vol. 50, 1993, pp. 571-576.

9. Fellenstein, J.A., "Brush Seals for Advanced Turbine Engines," Master's Thesis, Department of Mechanical and Aerospace Engineering, Case Westem Reserve University, 1994. 
Table 1: Composition of 1718 and H25 (Weight \%)

\begin{tabular}{|c|c|c|}
\hline Element & 1718 & H25 \\
\hline $\mathrm{C}$ & 19.0 & 20.0 \\
\hline $\mathrm{Ni}$ & 52.5 & 10.0 \\
\hline $\mathrm{Co}$ & - & 50.0 \\
\hline $\mathrm{Mb}$ & 3.0 & - \\
\hline $\mathrm{W}$ & -- & 15.0 \\
\hline $\mathrm{Nb}$ & 5.1 & -- \\
\hline $\mathrm{Ti}$ & 0.9 & - \\
\hline $\mathrm{Al}$ & 0.5 & - \\
\hline $\mathrm{Fe}$ & 18.5 & 3.0 \\
\hline $\mathrm{C}$ & 0.08 & 0.10 \\
\hline $\mathrm{Cl}$ & $0.15 \mathrm{max}$. & - \\
\hline $\mathrm{Mn}$ & - & 1.5 \\
\hline
\end{tabular}

Table 2: Brush Specimen and Current Brush Seal Design Geometries

\begin{tabular}{|c|c|c|}
\hline & Brush Specimen & Current Designs \\
\hline Bristle Materials & H25 & H25 \\
& & I718 \\
\hline Bristle Density & 175 Bristles/mm & $90-178$ Bristles/mm \\
& Bore Circumference & Bore Circumference \\
& (4450 Bristles/in & $(2300-4500$ Bristles/in \\
& Bore Circumference) & Bore Circumference) \\
\hline Bristle Area Ratio & 0.82 & $0.42-0.83$ \\
\hline Fence Height & $1.27 \mathrm{~mm}(0.050 \mathrm{in})$ & $1.27 \mathrm{~mm}(0.050 \mathrm{in})$ \\
\hline Bristle Angle & $45^{\circ}$ & $40^{\circ}-50^{\circ}$ \\
\hline
\end{tabular}


Table 3: Test Conditions

\begin{tabular}{|c|c|}
\hline Variable & Value \\
\hline Temperature & 20 or $650^{\circ} \mathrm{C}$ \\
& 68 or $1200^{\circ} \mathrm{F}$ \\
\hline Surface Speed & 1.99 or $23.94 \mathrm{~m} / \mathrm{s}$ \\
& 6.54 or $78.54 \mathrm{ft} / \mathrm{s}$ \\
(Motor Speed) & $(1,000$ or $12,000 \mathrm{RPM})$ \\
\hline Contact Force & 0.49 or $0.98 \mathrm{~N}$ \\
& 2.18 or $4.36 \mathrm{lbf}$ \\
(Test Load) & $(50$ g or $100 \mathrm{~g})$ \\
\hline
\end{tabular}

Table 4: Wear Factor Interpretation

\begin{tabular}{|c|c|}
\hline $\begin{array}{c}\text { Wear Factor } \\
\left(\mathrm{mm}^{3} \mathrm{~N} \cdot \mathrm{m}\right)\end{array}$ & Interpretation \\
\hline$>10^{-4}$ & High Wear \\
\hline $10^{-5}$ to $10^{-6}$ & Moderate to Low Wear \\
\hline$<10^{-7}$ & Low Wear \\
\hline
\end{tabular}

Table 5: I718 Journal Wear*

\begin{tabular}{|c|c|c|c|c|c|}
\hline \multicolumn{3}{|c|}{ Test Conditions } & & & \\
\hline $\begin{array}{l}\text { Temp. } \\
\left({ }^{\circ} \mathrm{C}\right)\end{array}$ & $\begin{array}{l}\text { Surface Speed } \\
(\mathrm{m} / \mathrm{s})\end{array}$ & $\begin{array}{l}\text { Contact } \\
\text { Force } \\
(\mathrm{N})\end{array}$ & $\begin{array}{l}\text { Average } \\
\text { Scar Depth } \\
(\mathrm{mm})\end{array}$ & $\begin{array}{l}\text { Wear Factor } \\
\left(\mathrm{mm}^{3} / \mathrm{N} \cdot \mathrm{m}\right)\end{array}$ & $\begin{array}{l}\text { Normalized } \\
\text { Scar Depth } \\
\text { (mm/Mrev) }\end{array}$ \\
\hline 20 & 1.99 & 0.49 & 4.55 & $2.6 \times 10^{-5}$ & 179 \\
\hline 20 & 1.99 & 0.98 & 0.23 & $6.1 \times 10^{-7}$ & 10.3 \\
\hline 20 & 23.94 & 0.49 & 0.71 & $3.8 \times 10^{-7}$ & 2.69 \\
\hline 20 & 23.94 & 0.98 & 0.92 & $4.0 \times 10^{-7}$ & 3.56 \\
\hline 650 & 1.99 & 0.49 & 0.17 & $1.2 \times 10^{-6}$ & 7.50 \\
\hline 650 & 1.99 & 0.98 & 0.02 & $3.6 \times 10^{-8}$ & 0.72 \\
\hline 650 & 23.94 & 0.49 & 0.14 & $5.1 \times 10^{-8}$ & 0.43 \\
\hline 650 & 23.94 & 0.98 & 0.26 & $7.3 \times 10^{-8}$ & 1.01 \\
\hline
\end{tabular}


Table 6: H25 Brush Wear *

\begin{tabular}{|c|c|c|c|c|c|}
\hline \multicolumn{3}{|c|}{ Test Conditions } & & Wear Factor & $\begin{array}{c}\text { Bristle Wear } \\
(\mathrm{mm} / \mathrm{Mm})\end{array}$ \\
\hline$\left({ }^{\circ} \mathrm{C}\right)$ & $\begin{array}{c}\text { Surface Speed } \\
(\mathrm{m} / \mathrm{s})\end{array}$ & $\begin{array}{c}\text { Contact } \\
\text { Force } \\
(\mathrm{N})\end{array}$ & $\begin{array}{c}\text { Bristle Wear } \\
(\mathrm{mm})\end{array}$ & $\begin{array}{c}\text { Wear } \\
\left(\mathrm{mm}^{3} \mathrm{~N} \cdot \mathrm{m}\right)\end{array}$ & 0.49 \\
\hline 20 & 1.99 & 0.49 & 0.340 & $2.6 \pm 2.3 \times 10^{-5}$ & 2.630 \\
\hline 20 & 1.99 & 0.98 & 0.795 & $8.1 \pm 4.0 \times 10^{-5}$ & 6.150 \\
\hline 20 & 23.94 & 0.49 & 0.119 & $2.1 \pm 1.6 \times 10^{-6}$ & 0.077 \\
\hline 20 & 23.94 & 0.98 & 0.135 & $1.2 \pm 0.5 \times 10^{-6}$ & 0.087 \\
\hline 650 & 1.99 & 0.49 & 0.030 & $6.1 \pm 4.2 \times 10^{-6}$ & 0.232 \\
\hline 650 & 1.99 & 0.98 & 0.031 & $3.2 \pm 1.9 \times 10^{-6}$ & 0.240 \\
\hline 650 & 23.94 & 0.49 & 0.061 & $6.0 \pm 0.4 \times 10^{-7}$ & 0.039 \\
\hline 650 & 23.94 & 0.98 & 0.110 & $9.7 \pm 1.1 \times 10^{-7}$ & 0.071 \\
\hline
\end{tabular}

* Standard Deviation based upon three repeated samplings.

Table 7: H25 Brush vs. 1718 Journal Friction Coefficient ${ }^{* *}$

\begin{tabular}{|c|c|c|c|}
\hline \multicolumn{3}{|c|}{ Test Conditions } & \\
\hline $\begin{array}{c}\text { Temp. } \\
\left({ }^{\circ} \mathrm{C}\right)\end{array}$ & $\begin{array}{c}\text { Surface Speed } \\
(\mathrm{m} / \mathrm{s})\end{array}$ & $\begin{array}{c}\text { Contact Force } \\
(\mathrm{N})\end{array}$ & Average Friction Coefficient \\
\hline 20 & 1.99 & 0.49 & $0.345 \pm 0.053$ \\
\hline 20 & 1.99 & 0.98 & $0.418 \pm 0.033$ \\
\hline 20 & 23.94 & 0.49 & $0.410 \pm 0.060$ \\
\hline 20 & 23.94 & 0.98 & $0.468 \pm 0.034$ \\
\hline 650 & 1.99 & 0.49 & $0.248 \pm 0.057$ \\
\hline 650 & 1.99 & 0.98 & $0.270 \pm 0.022$ \\
\hline 650 & 23.94 & 0.49 & $0.329 \pm 0.043$ \\
\hline 650 & 23.94 & 0.98 & $0.399 \pm 0.033$ \\
\hline
\end{tabular}

** Standard Deviation based upon nine repeated samplings. 


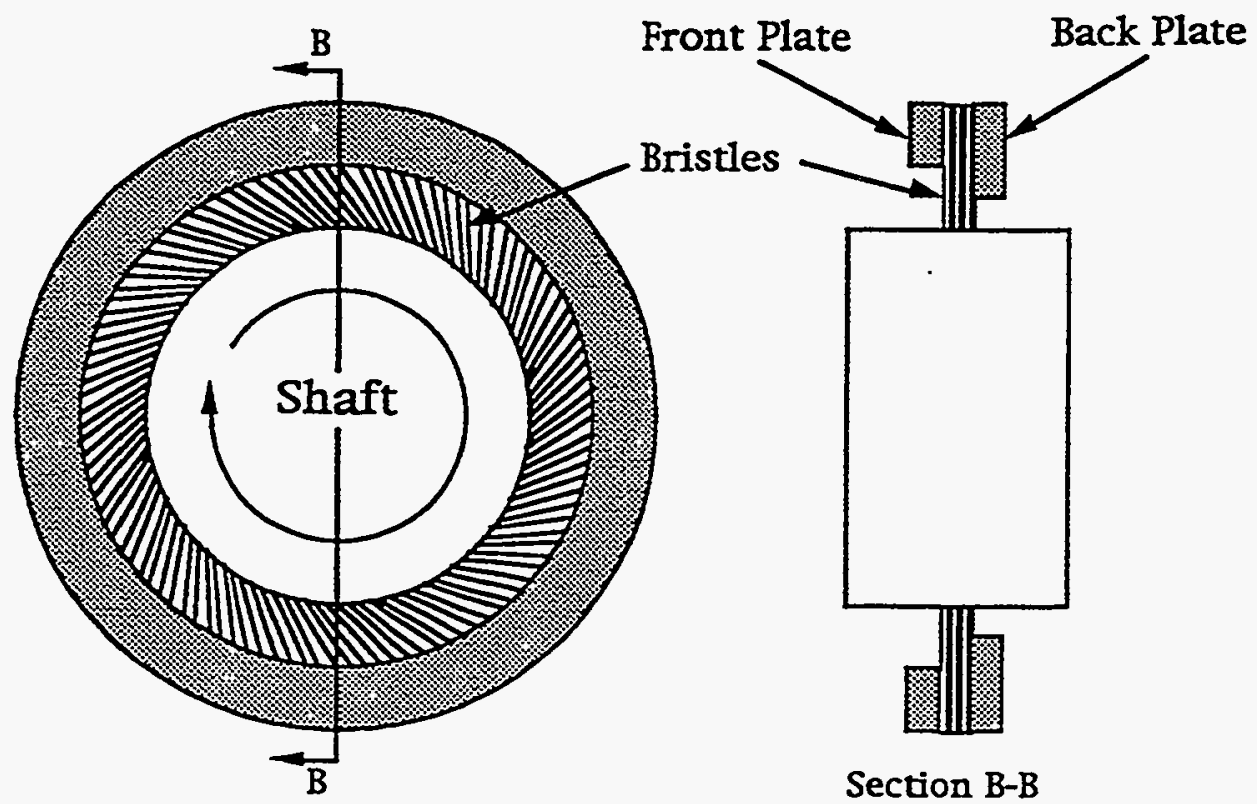

Figure 1.- Schematic of a bnush seal showing front and cross section views.
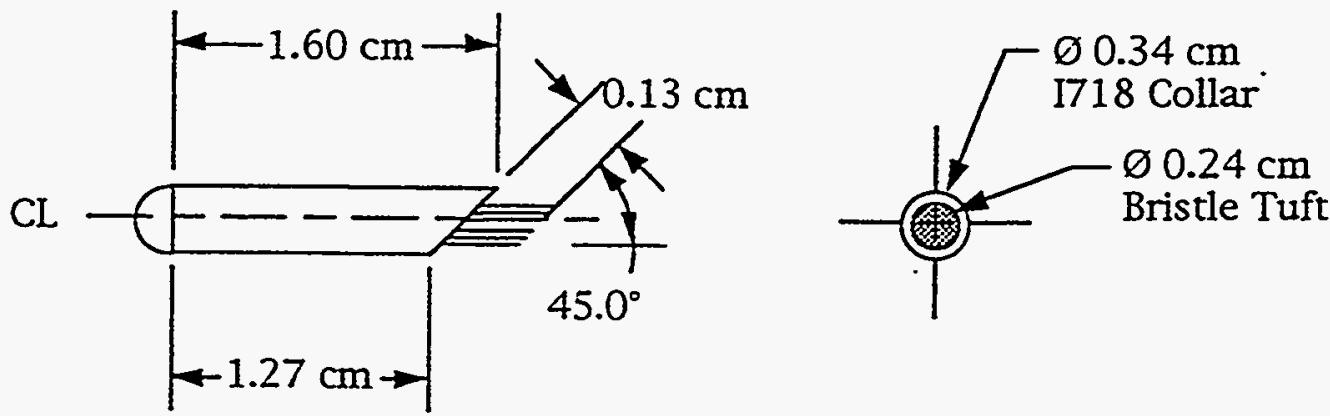

Figure 2.-Tuft specimen configuration showing dimensions and geometry. 


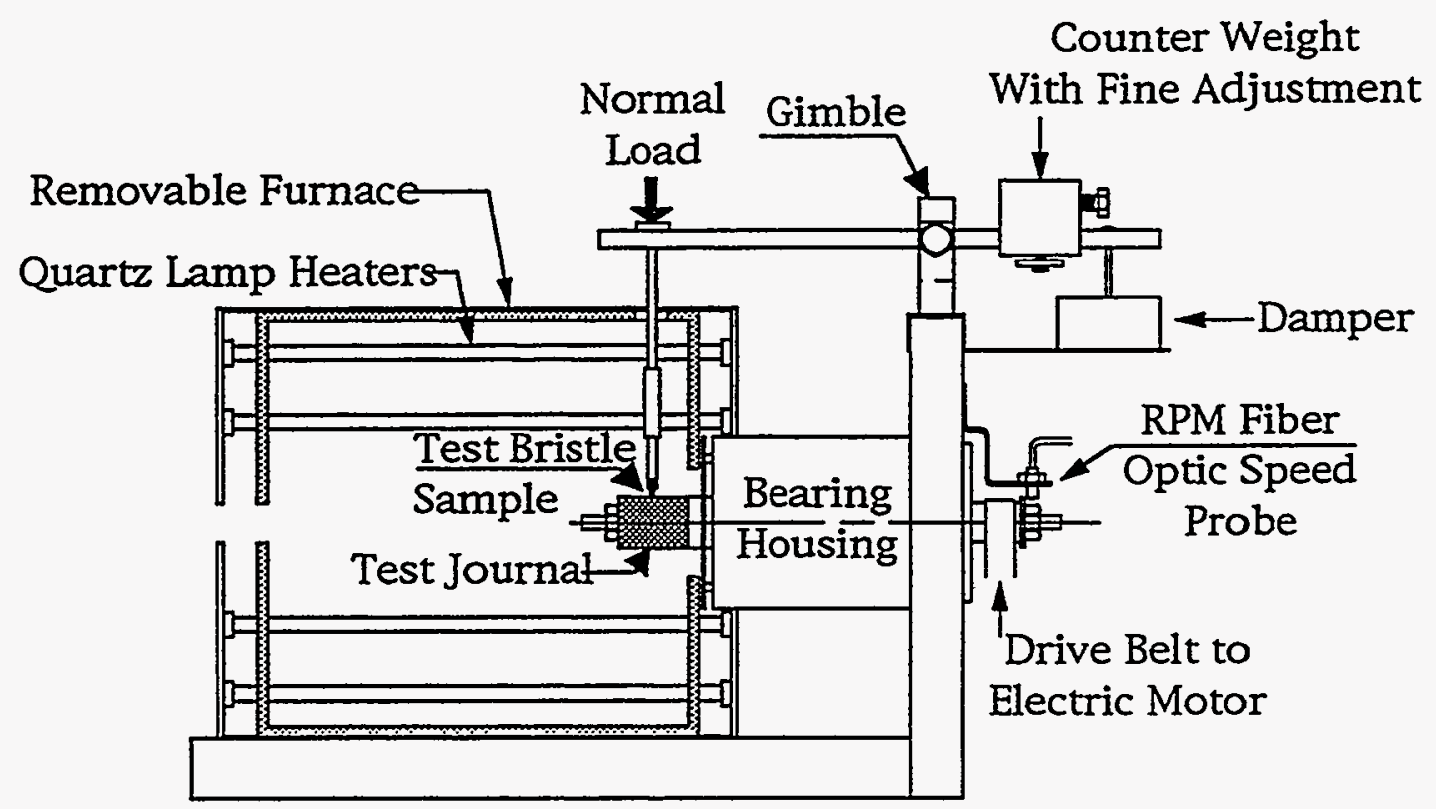

Figure 3.-Cross section side view of brush seal tuft test rig.

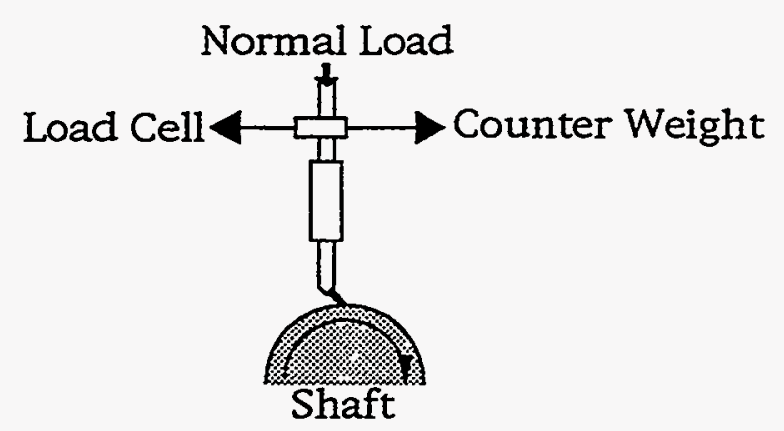

Figure 3a.-End view schematic of specimen arrangement in tuft test rig. 


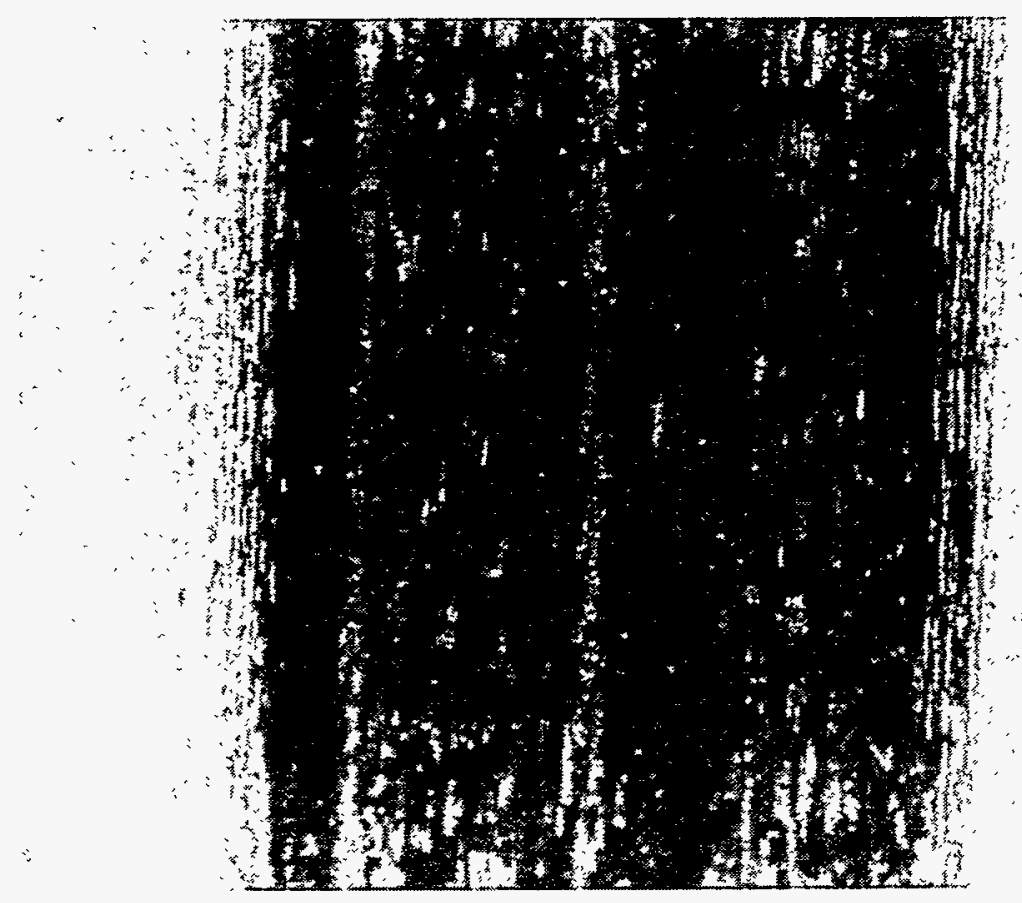

Figure 4.-Macrophotograph of 1718 superalloy journal wear track after sliding for $18 \mathrm{hr}$ against a $\mathrm{H} 25$ tuft at $650^{\circ} \mathrm{C}$ under a $0.98 \mathrm{~N}$ load.

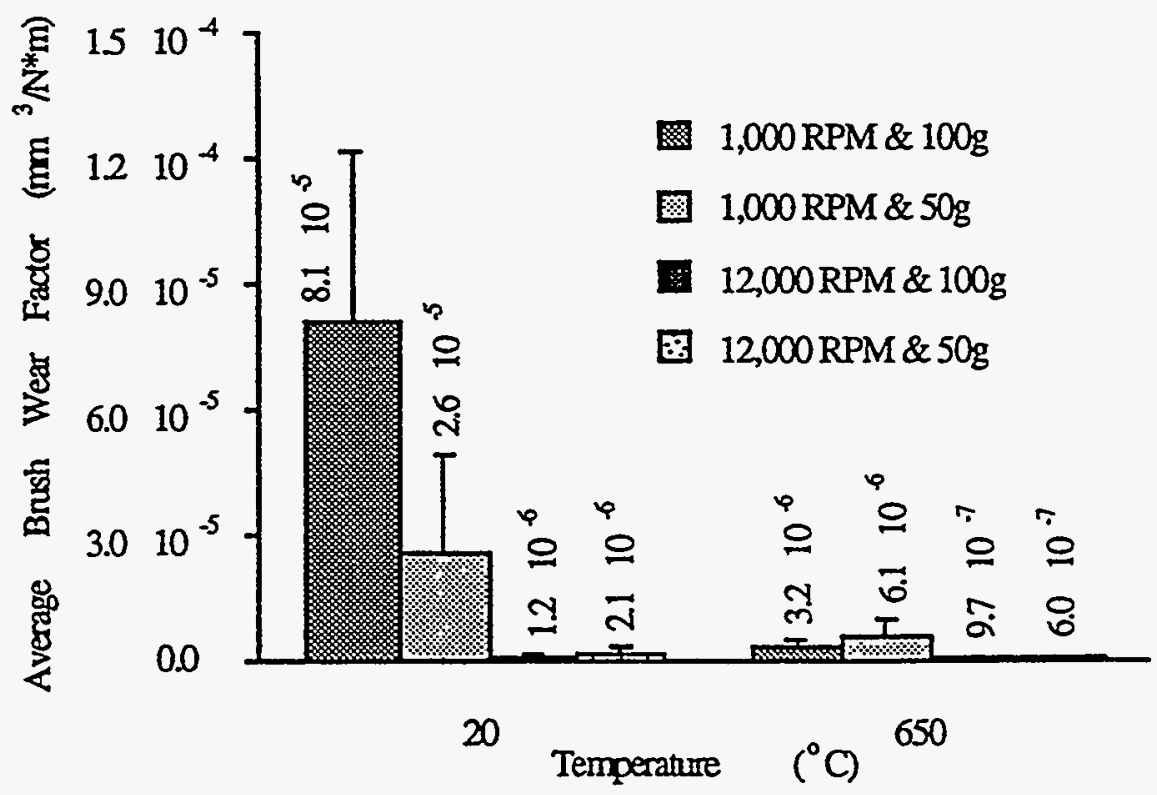

Figure 5.-Brush wear factor, in $\mathrm{mm}^{3} / \mathrm{N} \cdot \mathrm{m}$ for $\mathrm{H} 25$ cobalt based superalloy bristles sliding against 1718 nickel based superalloy shaft. Wear factor goal for adequate wear life is $10^{-8} \mathrm{~mm}^{3} / \mathrm{N} \cdot \mathrm{m}$. 


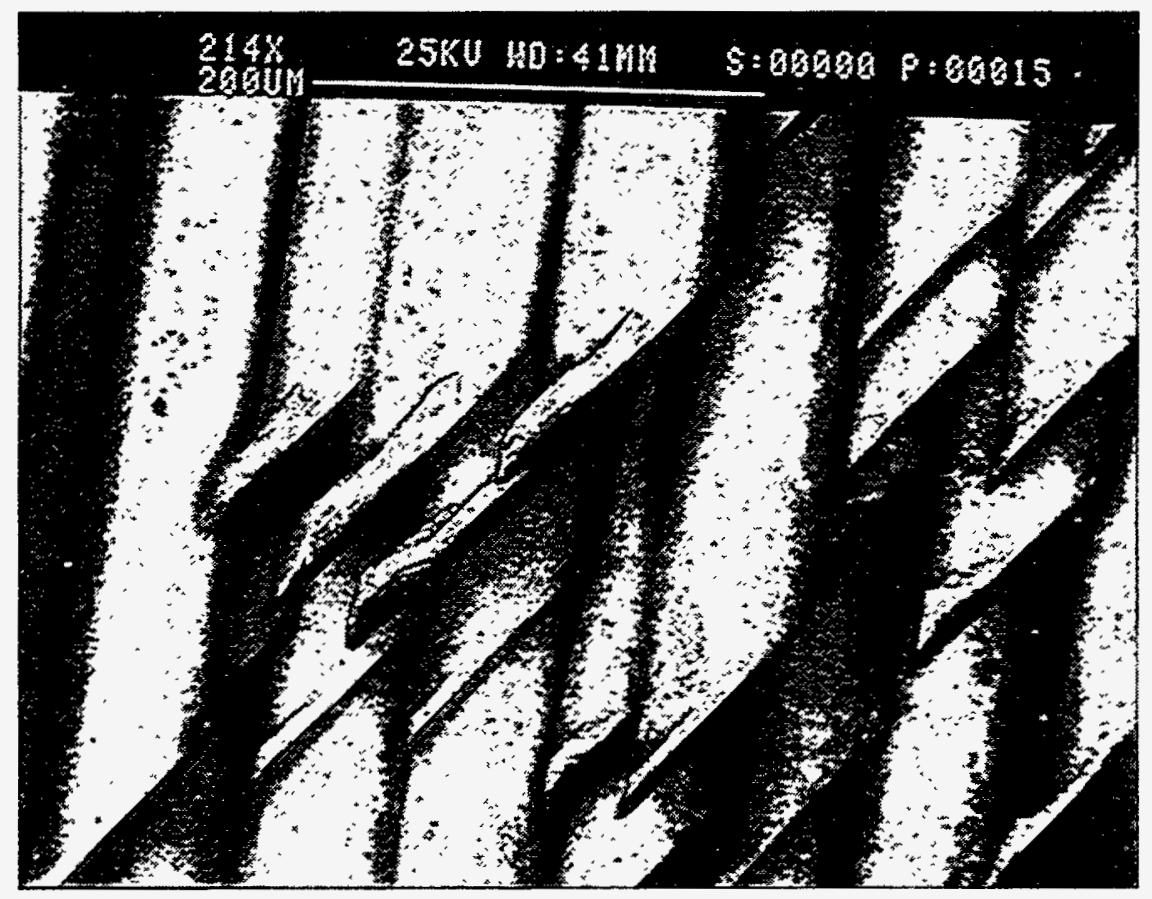

Figure 6. SEM photomicrograph of full scale brush seal bristle wear surface, edge-on. Note build up of wear debris on wire edge. From ref. 2.

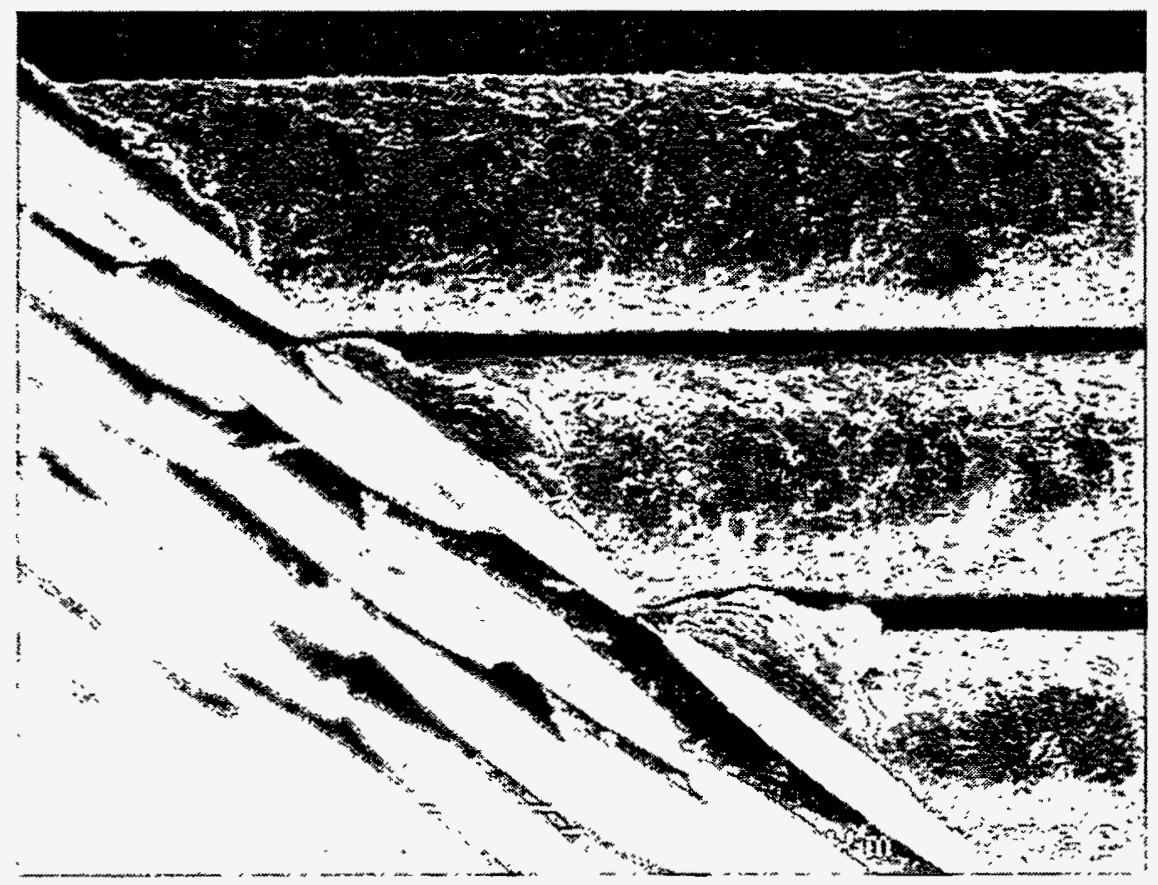

Figure 7.-SEM photomicrograph of tuft specimen bristle showing morphology (debris build up) similar to full seal specimens. 


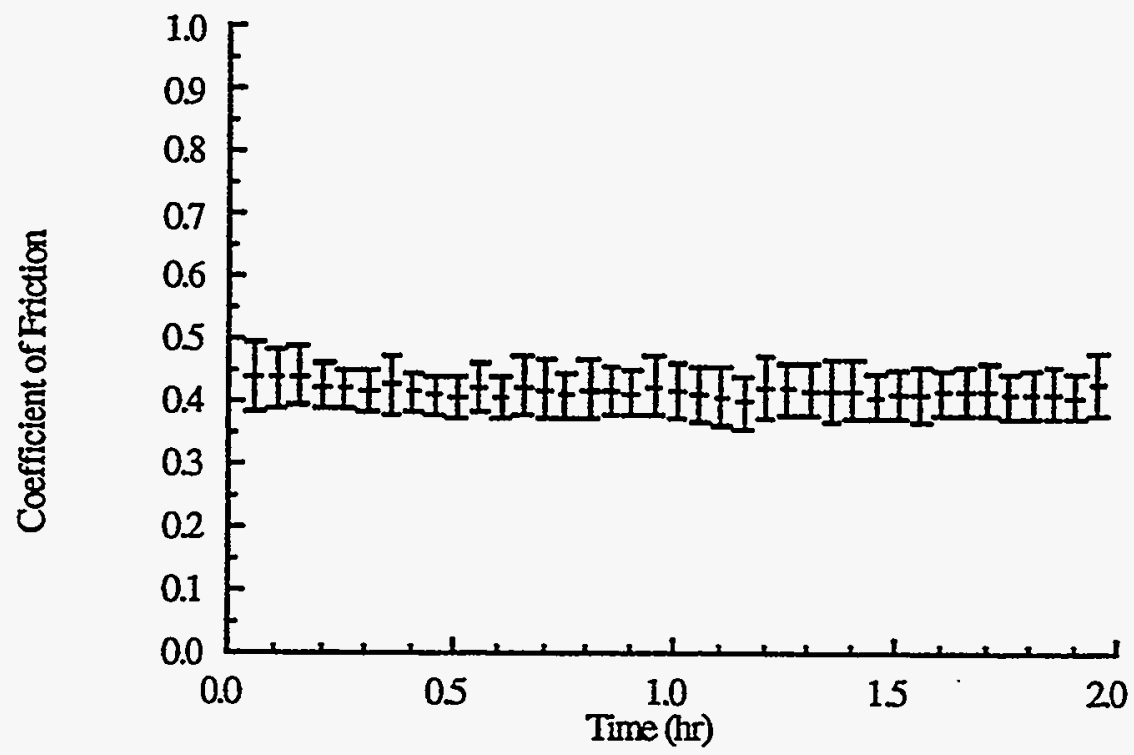

Figure 8. -Typical coefficient of friction vs. time plot from tuft test run at $20^{\circ} \mathrm{C}, 0.98 \mathrm{~N}$ load, and $1.99 \mathrm{~m} / \mathrm{s}$.

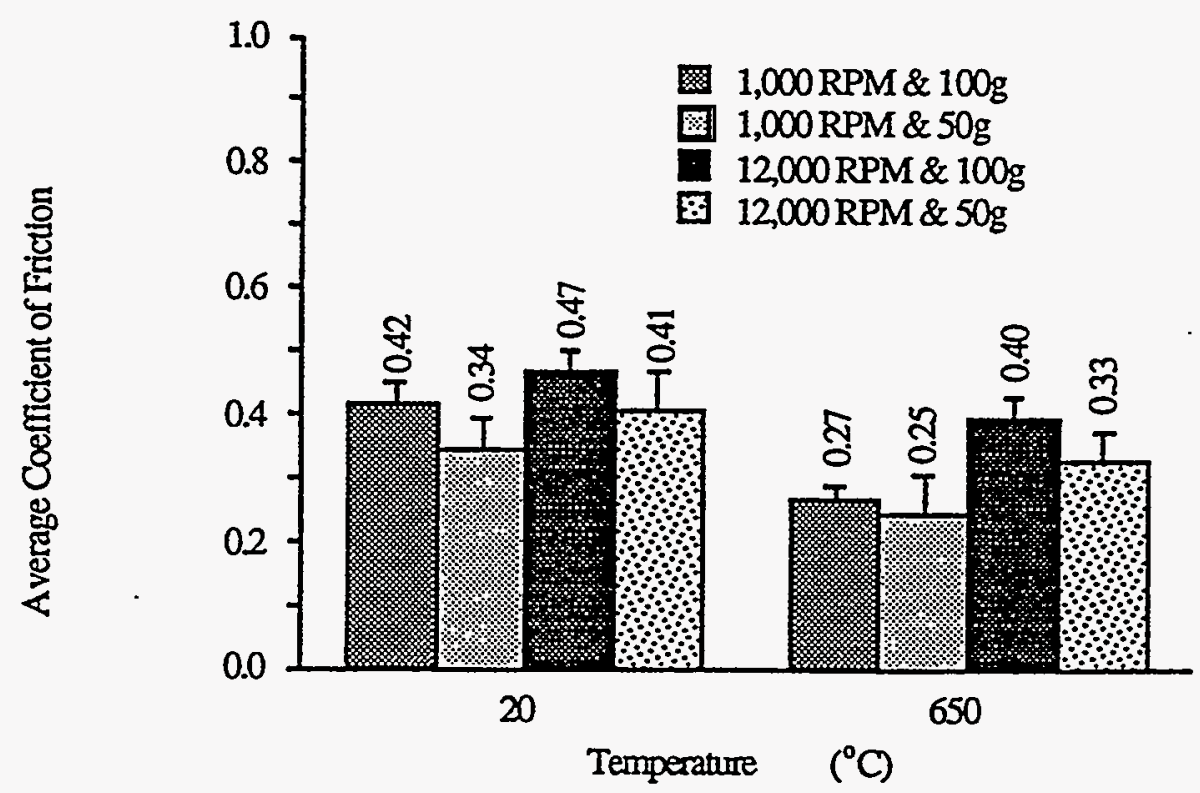

Figure 9.-Average friction coefficient of $\mathrm{H} 25$ tufts vs. 1718 journal under various test conditions. Error bars represent standard deviation of averages of 9 test runs. 


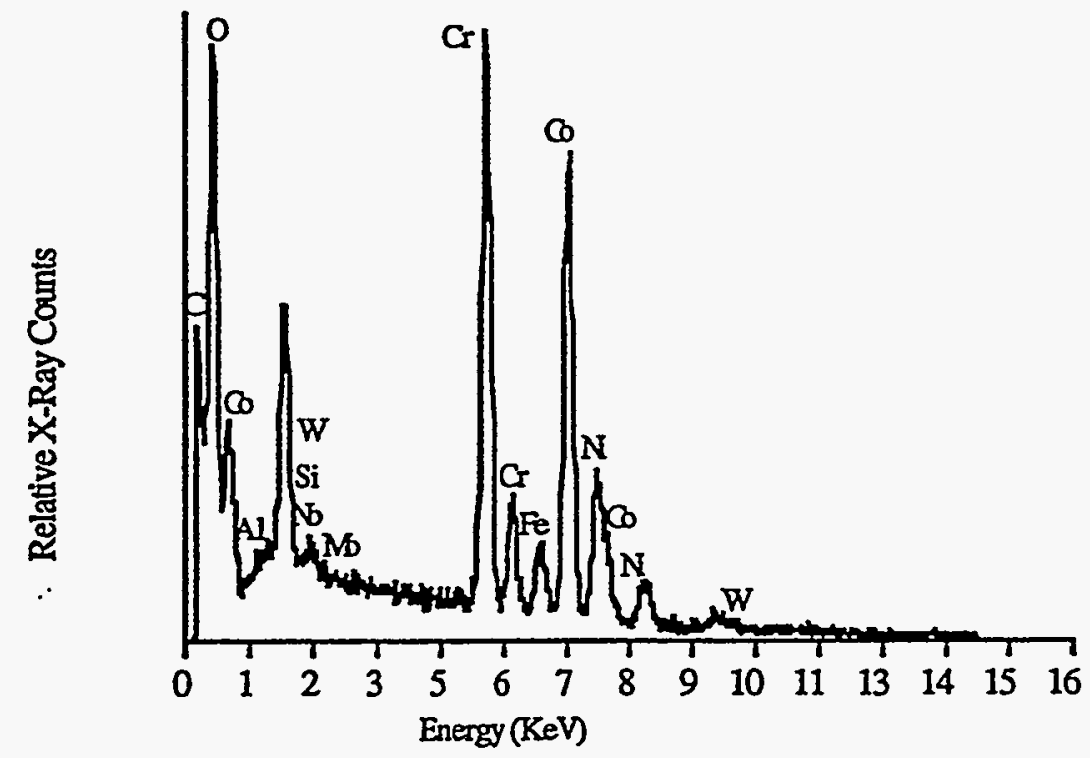

Figure 10.-Energy dispersive $x$-ray analysis of $\mathrm{H} 25$ tuft surface after sliding against 1718 journal at $650^{\circ} \mathrm{C}$. Presence of Mo, Nb, and Al suggest transfer from joumal to tuft surface during sliding. 
Public reporting burden for this collection of information is estimated to average 1 hour per response, including the time for reviewing instructions, searching existing data sources, gathering and maintaining the data needed, and completing and reviewing the collection of information. Send comments regarding this burden estimate or any other aspect of this collection of information, including suggestions for reducing this burden, to Washington Headquarters Services. Directorate for Information Operations and Reports, 1215 Jefterson Davis Highway, Suite 1204. Arlington. VA 22202-4302, and to the Otfice of Management and Budget, Papenwork Reduction Project (0704-0188). Washington, DC 20503.

\begin{tabular}{l|l|l|}
\hline 1. AGENCY USE ONLY (Leave blank) & 2. REPORT DATE & 3. REPORT TYPE AND DATES COVERED
\end{tabular}

4. TITLE AND SUBTITLE

April 1995

ANew Tribological Test for Candidate Brush Seal Materials Evaluation

6. AUTHOR(S)

James A. Fellenstein and Christopher DellaCorte
8. PERFORMING ORGANIZATION REPORT NUMBER

E-9169

National Aeronautics and Space Administration

Lewis Research Center

Cleveland, Ohio 44135-3191

WU-778-34-28

5. FUNDING NUMBERS

9. SPONSORING/MONITORING AGENCY NAME(S) AND ADDRESS(ES)

10. SPONSORINGMONITORING

AGENCY REPORT NUMBER

National Aeronautics and Space Administration

Washington, D.C. 20546-0001

NASA TM- 106753

DOE/NASA/50306-6

Corrected Copy

11. SUPPLEMENTARY NOTES

Final Repor. Prepared under Interagency Agreement DE-AI01-91 CE50306. James A. Fellenstein, Ohio Aerospace Institute, 22800 Cedar Point Road, Cleveland, Ohio 44142 and Christopher DellaConte, NASA Lewis Research Center. Prepared for the Annual Meeting sponsored by the Society of Tribologists and Lubrication Engineers, Chicago, Mlinois, May 15-20, 1095. Responsible person, Christopher DellaCorte, organization code 5140, (210) $433-6056$.

12a. DISTRIBUTIONAVAILABILTY STATEMENT

12b. DISTRIBUTION CODE

Unclassified - Unlimited

Subject Category 23

$\mathrm{UC}-373$

13. ABSTRACT (Maximum 200 words)

A new tribological test for candidate brush seal materials evaluation has been developed. The sliding contact between the brush seal wires and their mating counterface journal is simulated by testing a small tuft of wire against the outside diameter of a high speed rotating shaft. The test configuration is similar to a standard block on ring geometry. The new tester provides the capability to measure both the friction and wear of candidate wire and counterface materials under controlled loading conditions in the gram to kilogram range. A wide range of test condition speeds ( 1 to $27 \mathrm{~m} / \mathrm{s}$ ), temperatures $\left(25\right.$ to $\left.700^{\circ} \mathrm{C}\right)$, and loads $(0.5$ to $10 \mathrm{~N}$ ) enables the simulation of many of the important tribological parameter encountered by turbine engine brush seals. This paper describes the new test rig and specimen configuration and presents initial data for candidate seal materials comparing tuft test results and wear surface morphology to field tested seal components.

14. SUBJECT TERMS

Seals; Friction; Wear; High temperature; Solid lubricants; Turbine engines

15. NUMBER OF PAGES 18 16. PRICE CODE $\mathrm{A} 03$

\begin{tabular}{|c|c|c|}
\hline $\begin{array}{c}\text { 17. SECURTY CLASSIFICATION } \\
\text { OF REPORT } \\
\text { Unclassified }\end{array}$ & $\begin{array}{c}\text { 18. SECURTY CLASSIFICATION } \\
\text { OF THIS PAGE } \\
\text { Unclassified }\end{array}$ & $\begin{array}{c}\text { 19. SECURITY CLASSIFICATION } \\
\text { OF ABSTRACT } \\
\text { Unclassified }\end{array}$ \\
\hline
\end{tabular}

